\title{
Influence of nitrogen and organic fertilization in the production of pungence in the crop of chile jalapeño (Capsicum annum), in greenhouse and open sky
}

\section{Influencia de la fertilización nitrogenada y orgánica en la producción de pungencia en el cultivo de chile jalapeño (Capsicum annum), en invernadero y en cielo abierto}

\author{
ARREGUIN-SOTO Javier $\dagger^{*}$, ZUÑIGA-MALDONADO, Walter Manuel and ORTEGA-GARCIA, \\ Nicolas
}

Innovación Agrícola Sustentable, Instituto Tecnológico Superior de Salvatierra, Manuel Gómez Morín 300, col. Janicho, 38900, Salvatierra, Guanajuato, México, Departamento de Posgrado e Investigación

ID $1^{\text {st }}$ Author: Javier, Arreguin-Soto / ORC ID: 0000-0003-2204-0209, Researcher ID Thomson: X-3004-2018, CVU CONACYT ID: 143848

ID $1^{\text {st }}$ Coauthor: Walter Manuel, Zuñiga-Maldonado

ID $2^{\text {nd }}$ Coauthor: Nicolas, Ortega-Garcia

DOI: $10.35429 / E J R N .2019 .9 .5 .17 .20$

Received June 28, 2019; Accepted December 22, 2019

\begin{abstract}
Capsaicin and dihydrocapsaicin are responsible for $90 \%$ of the pungency of the fruit; the rest of the capsaicinoids participate to a lesser extent in the itching, but contribute strongly to the diversity of spicy flavors in the different species of Capsicum. In the present project the application of 7 treatment $\mathrm{T} 1=$ Chemical, $\mathrm{T} 2=$ Chemical + Bioferment, T3 $=$ Chemical + Leached, T4 = Bioferment, $\mathrm{T} 5=$ Leached, $\mathrm{T} 6=$ Bioferment + Leached, $\mathrm{T} 7=$ Chemical + Leached + Bioferment, in greenhouse was evaluated and in open sky, a randomized block design with three repetitions was established. The variables evaluated were plant height, temperature, relative humidity, production weight, fresh weight, root depth, dry weight and $\mathrm{pH}$. The data generated in this research indicate that the treatment that generated the most amount of capsaicinoids was the chemical treatment in the greenhouse with $37.7 \mathrm{ml}$ of capsaicinoids and in the open sky with $36.96 \mathrm{ml}$.
\end{abstract}

Organic Fertilization, Chemical Fertilization, Pungence

\section{Resumen}

La capsaicina y la dihidrocapsaicina son responsables de $90 \%$ de la pungencia del fruto; el resto de los capsaicinoides participan en menor medida en el picor, pero contribuyen fuertemente a la diversidad de sabores picantes en las diferentes especies de Capsicum. En el presente proyecto se evaluó la aplicación de 7 tratamiento T1= Químico, T2=Químico+ Biofermento, T3= Químico + Lixiviado, $\mathrm{T} 4=$ Biofermento, $\mathrm{T} 5=$ Lixiviado, $\mathrm{T} 6=$ Biofermento + Lixiviado, T7= Químico + Lixiviado + Biofermento, en invernadero y en cielo abierto, se estableció un diseño de bloques al azar con tres repeticiones. Las variables evaluadas fueron altura de planta, temperatura, humedad relativa, peso de producción, peso fresco, profundidad de raíz, peso seco y $\mathrm{pH}$. Los datos generados en esta investigación, indican que el tratamiento que genero mayor cantidad de capsaicinoides fue el tratamiento químico en invernadero con $37.7 \mathrm{ml}$ de capsaicinoides y en cielo abierto con 36.96 $\mathrm{ml}$.

Organic fertilization, Chemical Fertilization, Pungence

Citation: ARREGUIN-SOTO Javier, ZUÑIGA-MALDONADO, Walter Manuel and ORTEGA-GARCIA, Nicolas. Influence of nitrogen and organic fertilization in the production of pungence in the crop of chile jalapeño (Capsicum annum), in greenhouse and open sky. ECORFAN Journal-Republic of Nicaragua. 2019. 5-9: 17-20

$\uparrow$ Researcher contributing as first author 


\section{Introduction}

In Mexico there are more than 100 varieties of chili, the most common of which are green chili, habanero, bell pepper, jalapeño and poblano chili. It should be noted that the production of chili in the country is considered one of the most important primary economic activities, since each year its production generates more than 22 billion pesos, which in addition to benefiting the economy of more than 12 thousand producers in Mexico (Muñoz. 2017).

The consumption of chili is mainly due to its spicy taste, caused by the presence of capsaicinoids, a group of acid amides derived from vanillylamine, which are synthesized and accumulated in the placental tissue. Different capsicum species may vary in degree of itching, which is related to their ability to accumulate capsaicinoids. The habanero chile (C. chinense) is considered the hottest; However, some varieties of C. annuum can reach similar levels, depending on the conditions in which they are grown (Vázquez. 2007).

Fertilization should be done precisely, planned and above all avoiding the use of compounds and / or products other than those indicated for the type of crop, soil, climate, etc. To cover effectiveness, organic and chemical fertilization should be taken into account as an economically and ecologically feasible alternative for production, in which there is a better use of nutrients and that they are available efficiently and quickly for plants (Barrales. 2010).

\section{Problem Statement}

Pungency is the spicy taste of the fruits of the Capsicum genus, and this is due to the presence of compounds called capsaicinoids that are found mainly in the placental tissue, however the presence of these compounds is affected by various factors such as environment and fertilization. The pungency in chili is due to the organic compound called capsaicin having great importance not only because it is the substance that causes the itching (pungency) in the chili, but also of vital importance since it is used for food preservation, it has anti -Microbial and antifungal, inhibiting the development of certain pathogens.
This is why the alternative of open sky and greenhouse fertilization is sought to identify if they influence the production of pungency in greater quantity, in order to provide sufficient quantity to the use in the capsaicin industry.

\section{Objectives}

\section{General}

Evaluate the influence of organic and nitrogen fertilization on the pungency of jalapeño pepper in the open sky and greenhouse

\section{Specific}

- Determine the pungency content of jalapeno pepper treated with 7 treatments Evaluate the effect that organic and chemical fertilization has on the pungency of open-pit jalapeño pepper and greenhouse

\section{Methodology}

The experiment was established under an experimental design by random blocks, where seven treatments with three repetitions will be evaluated.

Where the treatments are:

$$
\begin{aligned}
& \text { T1 }=\text { Chemical } \\
& \text { T2 }=\text { Chemical }+ \text { Bioferment } \\
& \text { T3 }=\text { Chemical }+ \text { Leaching } \\
& \text { T4 }=\text { Bioferment } \\
& \text { T5 }=\text { Leached } \\
& \text { T6 }=\text { Bioferment }+ \text { Leaching } \\
& \text { T7 }=\text { Chemical }+ \text { Leaching }+ \text { Bioferment }
\end{aligned}
$$

\begin{tabular}{|c|c|c|}
\hline T7, R1 & T5,R2 & T2, R1 \\
\hline T3, R2 & T7, R3 & T5, R1 \\
\hline T1, R1 & T1, R3 & T2, R3 \\
\hline T6, R1 & T4, R3 & T5, R3 \\
\hline T2, R2 & T6, R2 & T3, R3 \\
\hline T1, R2 & T3, R1 & T7, R2 \\
\hline T4, R2 & T6, R3 & T4, R1 \\
\hline
\end{tabular}

Table 1 Experimental design for open sky and greenhouse

\section{Contribution}

Organic fertilization in a profitable alternative if the producer wants to obtain greater production, and for greater pungency the application of chemical fertilizer is recommended 


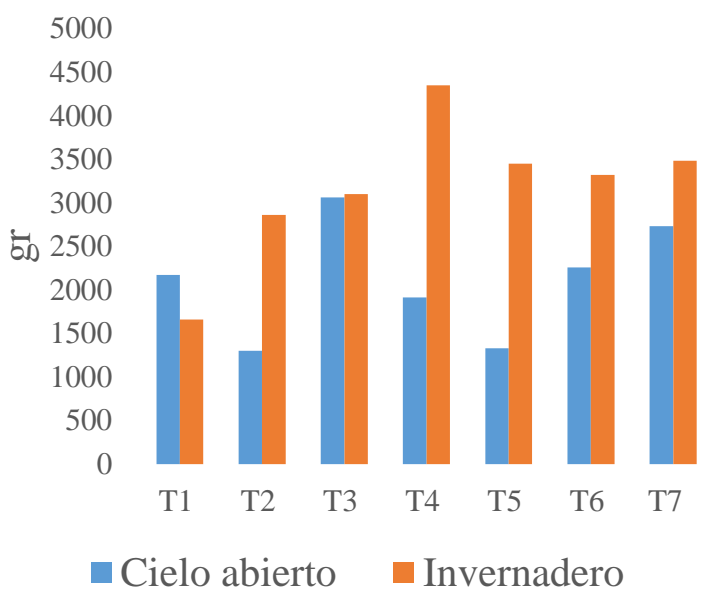

Graphic 1 Weight of production in open sky and greenhouse

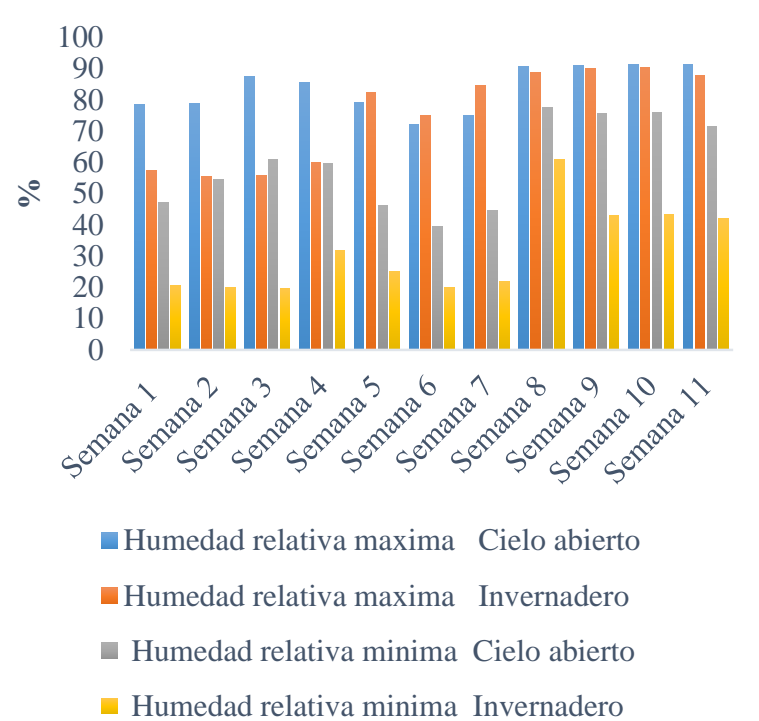

Graphic 2 Record of temperature and humidity in open sky and greenhouse

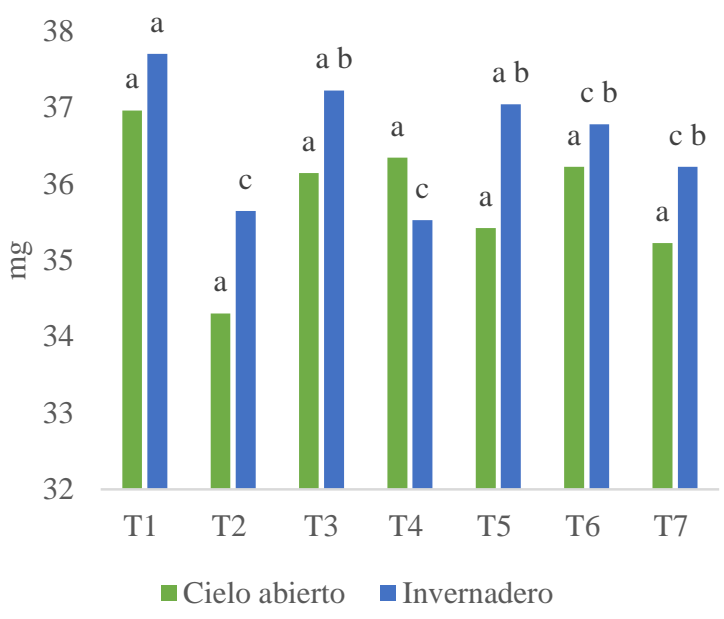

Graphic 3 Capsaicinoids

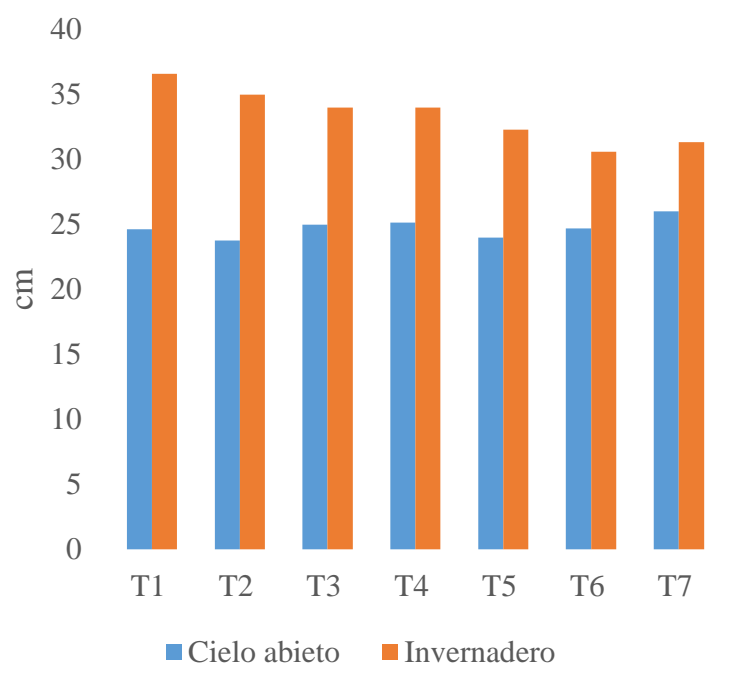

Graphic 4 Plant height

\section{Conclusions}

For the height variable, the treatments established in the greenhouse had a different behavior having a greater height than the treatments established in the open sky.

According to the root depth variable, treatments T4 (B), T2 $(\mathrm{Q}+\mathrm{B})$ and $\mathrm{T} 6(\mathrm{~B}+\mathrm{L})$ showed a greater difference, being those established in the greenhouse those that presented larger roots, while treatments $\mathrm{T} 3(\mathrm{Q}+$ L), T4 (B), T5 (L) and T7 (Q + L + B) showed no difference because they behaved similarly both in the greenhouse and in the open sky having shorter roots.

According to the pungency the treatments established in the open sky had no significant difference according to the Tukey test (P> 0.05). On the other hand, in greenhouse the treatments T1, T2 and T4 had a difference, with T1 being the one with the highest amount of capsaicinoids with 37.7 and the one with the lowest capsaicinoids was $\mathrm{T} 4$ with a total of 35.52 .

With the data obtained in this investigation, it is concluded that the treatment that gave the best result in both greenhouse and open sky was the chemical treatment since it gave greater pungency, this means that the bioferment and leaching do not influence the production of capsaicin are however the temperature and relative humidity if since in greenhouse conditions the levels of pungency were greater than the levels of pungency in the open sky. 


\section{Recommendations}

Organic fertilization in a profitable alternative if the producer wants to obtain greater production, and for greater pungency the application of chemical fertilizer is recommended

The optimal conditions for the production of capsaicin are in the greenhouse since there are adequate temperatures and humidity for its production and with the proper fertilization better results are obtained.

It is recommended to repeat the experiment and thus corroborate the results obtained and improve the information on the production of capsaicin since it is an alternative of great potential for the farmer.

\section{References:}

Felipe Vázquez.2007. La biosíntesis de capsaicinoides, el principio picante del chile. Recuperado de: https://www.revistafitotecniamexicana.org/docu mentos/30-4/2r.pdf

Lizette Borges-Gómez.2008.Capsaicinoides en chile habanero (Capsicum chinense Jacq.) bajo diferentes condiciones de humedad y nutrición. Recuperado de: http: //www.scielo.org.mx/scielo.php?script=sci_artt ext\&pid=S0187-5779201000 0100004

Lino Sánchez Segura.2016. El picor del chile, biosíntesis de la capsaicina y diferenciación morfológica. Recuperado de: http://www.revistaciencias.unam.mx/pt/ 201revistas/revista-ciencias-118-119/1978-el-picordel-chile-bios\%C3\%ADntesis-de-la-capsaicinay-diferenciaci\%C3\%B3n-

morfol\%C3\%B3gica.html]

TOMAS M. Little.2018.Metodos estadísticos para la investigación en la agricultura. México: Trillas 